\title{
CORRELATION OF THE RISK OF OSTEOPOROTIC FRACTURE IN 10 YEARS CALCULATED BY THE FRAX METHOD IN RHEUMATOLOGICAL AND ENDOCRINOLOGICAL DISEASES
}

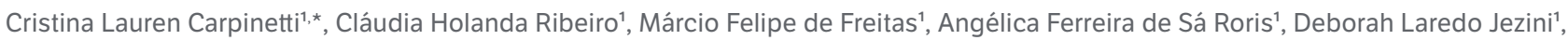
Sandra Lúcia Euzébio Ribeiro ${ }^{1}$

1.Universidade Federal do Amazonas, Manaus (AM), Brazil.

*Corresponding author: crislaurencarpinetti@gmail.com

\section{BACKGROUND}

Osteoporosis is characterized by a decrease in bone mass and deterioration of the microarchitecture of the bone tissue, increasing susceptibility to fractures, thus increasing morbidity and mortality. In Brazil, the prevalence of fractures is 11 and $23.8 \%$. However, only $6 \%$ of the adult population is aware of their diagnosis of osteoporosis. The Fracture Risk Assessment Tool (FRAX) facilitated the review of the risk of bone fractures. Fracture Risk Assessment Tool Brazil (FRAX-Brazil) is an algorithm that calculates the probability of bone fractures, based on clinical aspects and bone densitometry (DXA) for femur and other bones in the next 10 years. The objective of the present research was to identify the fracture risks of patients with rheumatological and endocrinological diseases through FRAX-Brazil.

\section{MATERIALS AND METHODS}

Cross-sectional study from September/2019 to September/2020. The study included people of both sexes and age $\geq 40$ with diagnoses of rheumatoid arthritis (RA), ankylosing spondylitis (AS), psoriatic arthritis (PSA), fibromyalgia (FM) and/or type 2 diabetes mellitus (T2D) and control group healthy (CG). All data necessary to use the FRAX-Brazil online platform were collected to calculate the risk of major osteoporotic and hip fractures in 10 years, with results analysed using measures of position and variability.

\section{RESULTS}

From 255 patients evaluated, the mean age was 54.45 years old, of which $66.27 \%$ were female gender and $33.73 \%$ male. Of these 255: 68 had RA, 27 AS, 12 PSA, 45 FM, 50 T2D and 100 healthy control (CG). Of these, 37 (14.51\%) had a high risk of osteoporotic fracture requiring therapeutic intervention, 127 (49.80\%) had a medium risk, requiring DXA for clarification and 91 (35.69\%) had a low risk. The risks obtained for patients with rheumatological and endocrine diseases were generally medium for major fractures and low for hip fractures, besides involving $94.59 \%$ of the high-risk portion, exceeding the risks of the healthy group, which mainly concentrated medium risk and the largest parcel of low risk.

\section{CONCLUSION}

The FRAX-Brazil tool associated patients with rheumatological and/or endocrinological disorders to greater chances of high and medium fracture risks and, consequently, needs for risk monitoring and management. Thereby, FRAX-Brazil is an important tool for observation and clinical decision, since it works properly with clinical data, allowing early therapeutic intervention and selection of patients for DXA, containing expenses, and providing for preventing fractures and identifying with greater availability and easy diagnoses of osteoporosis.

\section{REFERENCES}

1. Araújo IM, Parreiras-e-Silva LT, Carvalho AL, Elias Junior J, Salmon CEG, Paula FJA. Insulin resistance negatively affects bone quality not quantity: the relationship between bone and adipose tissue. Osteoporosis International. 2020;31:1125-33. https://doi. org/10.1007/s00198-020-05365-5 
2. Bastos-Silva Y, Aguiar LB, Pinto-Neto AM, Baccaro LF, Costa-Paiva L. Correlation between osteoporotic fracture risk in Brazilian postmenopausal women calculated using the FRAX with and without the inclusion of bone densitometry data. Arch Osteoporos. 2016;11:16. https://doi.org/10.1007/s11657-015-0255-y

3. Bellan M, Pirisi M, Sainaghi PP. Osteoporose na artrite reumatoide: papel do sistema vitamina D/hormônio paratireóideo. Rev Bras Reumatol. 2015;55(3):256-63. https://doi.org/10.1016/j.rbr.2014.10.007

4. Bringel AL, Andrade KFS, Silva Júnior ND, Santos GG. Suplementação nutricional de cálcio e vitamina D para a saúde óssea e prevenção de fraturas osteoporóticas. Revista Brasileira de Ciências da Saúde. 2015;18(4), 353-58. https://doi.org/10.4034/ RBCS.2014.18.04.11

5. Harvey NC, McCloskey EV. Falhas e soluções na saúde dos ossos: um modelo global para melhorias. Nyon: International Osteoporosis Foundation; 2016. 39 p.

6. Pinheiro MM, Ciconelli RM, Martini LA, Ferraz MB. Risk factors for recurrent falls among Brazilian women and men: the Brazilian Osteoporosis Study (BRAZOS). Cad Saúde Pública. 2010;26(1):89-96. https://doi.org/10.1590/S0102-311X2010000100010

7. Pinheiro MM, Eis SR. Epidemiology of osteoporotic fractures in Brazil: what we have and what we need. Arq Bras Endocrinol Metab. 2010;54(2):164-70. https://doi.org/10.1590/S0004-27302010000200012

8. WHO Scientific Group. Prevention and management of osteoporosis: Report of a WHO Scientific Group. World Health Organization. WHO technical report series. 2003;921.

9. Zerbini CAF, Albergaria BH. The Brazilian FRAX model: an introduction. Rev Assoc Med Bras. 2018;64(6), 481-83. https://doi. org/10.1590/1806-9282.64.06.481 